\title{
ASSERTIVE SPEECH ACTS IN MATA NAJWA PROGRAM OF EPISODE GARA-GARA CORONA
}

\author{
Julisah Izar', Mhd Muslim Nasution'2, Mie Ratnasari ${ }^{3}$ \\ Universitas Jambi ${ }^{1}$ \\ Universitas Islam Negeri Sumatera Utara ${ }^{2}$ \\ Universitas Medan Area ${ }^{3}$ \\ julisahiar@unja.ac.id
}

\begin{abstract}
The main objective of this study is to find out the types and functions of assertive speech acts that appear in Mata Najwa program in episode Gara-Gara Corona. The method used in this study is a qualitative descriptive method by analyzing and explaining the data obtained. The data in this study were speech segments in the Mata Najwa episode Gara-Gara Corona which indicate assertive speech acts. The data source in this study is the video of the program entitled "gara-gara Corona" taken from Youtube, which was published by Narration Newsroom on March 13, 2020. The steps taken in data collection techniques were, firstly downloading video from Youtube, the second listens to the utterances, and the third transcribes the utterances into written language. Then the speech data obtained was selected based on research questions related to the types and functions of assertive speech acts. At the stage of presenting the results of the analysis, it was presented using an informal presentation method, namely presentation using ordinary words. The results showed that the assertive speech act types that appeared in the event were 23 pairs of utterances, consisting of 11 pairs of assertive speech acts telling, 6 pairs of assertive speech acts stated, 3 pairs of assertive speech acts suggest, and 3 pairs of utterances assertive speech acts boast.
\end{abstract}

Keywords: Assertive Speech Acts, Mata Najwa Program, Types and Functions

\section{INTRODUCTION}

As tool of communication, according to Chaer (1994:45) language is used by speaker and speech partner to cooperate, so the goal is achieved. Line with that, Izar (2020) stated that as a social creature, humans certainly do communication activities as one of their needs to interact with one another. The smooth communication will be happened if speaker and speech partner can understand the context of conversation clearly. Paradita (2015) stated that a speech that is conveyed by speaker has meaning and function, one of them is to give information to speech partner.

According to Kusumaningrum (2018) the choice of how to communicate depends on various factors including age, occupation, social level, background, and other social functions. In communicating, speaker and speech partner use various speech acts in it. Speech act has various function based on the context. One of speech acts that are found in speech is assertive speech act. Elinni (2014) said that by the language, humans can express everything that is in their mind.

Assertive speech act is speech act binding speaker on the truth that they talk. Kinds of speech act are reporting, explaining, showing etc. assertive speech act can be found in daily life. 
Furthermore assertive speech act can also be found in a seminar. When conducting seminar, kind of assertive speech acts is explaining. This speech act comes naturally while the person is explaining about the explained material. Assertive speech act can also be found in a event that present information like talk show. Speech conveyed by interviewees in talk show will have a variety of different speech act and with different function. Furthermore the different background will also take effect toward language used during the event taking place. Mata Najwa has presented many interviewees with various backgrounds, so that thing will lead to a variety of assertive speech act that is used.

\section{REVIEW OF LITERATURE}

According to Yule (2006: 92), assertive speech act is speech acts that express the speaker's beliefs about matters of external reality. Another opinion is expressed by Tarigan (1990: 47) that assertive speech act is speech acts that involve the speaker on the truth of the prepositions expressed. So the statement stated by the assertive speech act is a statement which the speaker believes to be true, it can also be said that the statement stated with this assertive speech act binds the speaker to the truth spoken.

Speech act is meant how people do speech and action at once. Ramanda (2017) states that Speech acts is speech activities that are produced as part of social interaction it means that speech act is linguistics of performance including in pragmatic study that focus on meaning in the speech.

Speech act is communication used by speaker to inform to interlocutor, with special goals and special ways to meet degree of politeness in speaking. In speaking, speech act is right thing we do. Austin (1962: 100-102) says that in talking speech, someone does three things at once such as locutionary act, illocutionary act and perlocutionary act.

Assertive speech act is included in illocutionary act. According to Austin (1962: 108) Illocutionary is an act done by saying a speech having certain power presenting function of speech based on the context. Searle (in Leech, 1993:164) divide illocutionary act into 5 categories, such assertive, directive, commissive, expressive and declarative. This research focuses on assertive speech act, so the theory that becomes the reference is alluding to the ins and outs of assertive speech acts.

According to Leech (in Sudaryat, 2009:140) assertive sentence is the sentence that function to express the truth of information. In this speech act, speaker is bound on truth that is uttered. Yule (2006: 92) says that assertive speech acts are speech acts that express the speaker's beliefs about matters of external reality. so while talking, the speaker is sure about the truth of the speech.

According to Searle (in Tarigan, 1990: 46) this speech act is bound to the truth of the proposition expressed. This type of speech acts is like stating, explaining, showing, and so on. The functions of these types are as follows: (a) stating: speech function of stating is a speech or expression to explain, to describe something to interlocutor; (b) telling: speech function of telling is speech informing something to interlocutor; (c) suggesting: speech function of suggesting is speech or expression that gives opinion to someone to do what is suggested; (d) making proud: speech function of making proud is speech or expression that is used to state pride; (e) reporting: speech function of reporting is to state information to someone with view to do something.

This study elaborates assertive speech act that is used in talk show Mata Najwa in episode Gara - Gara Corona (because of Corona). The main purpose of this study is to know types and functions of assertive speech act in the talk show. This study is hoped to give contribution in pragmatics study and next researches, especially in giving opinion of kind and function of assertive speech act. 


\section{METHOD}

This is a descriptive study with qualitative approach because the problem that was scrutinized needs careful observation or research, tries to describe and makes general conclusions. Surakhmad (1978: 739) states that descriptive study is a study that tries to describe and analyze data from the stage of data collection, data preparation, and interpretation analysis of data. While qualitative was used because this research did not involve statistical calculation. The data in this research are segment of speech in Mata Najwa in episode of Gara - gara Corona (because of Corona) that identified assertive speech act. The data source in this research is the video in Mata Najwa talk show titled "Gara - Gara Corona (because of Corona) " taken fromm internet media (youtube) published by Narasi Newsroom at March 13th 2020. Steps conducted in technique of data collection are first, download the video from youtube, second, listen the speech and third, transcribe these utterances into written language. Next, the data of speech are chosen based on research questions about kinds and functions of assertive speech act. At the stage of the analysis result, it is presented using an informal presentation method, namely presentation using ordinary words.

\section{FINDINGS AND DISCUSSION}

In Mata Najwa episode "Gara - Gara Corona" there are 7 interviewees, they are Anies Baswedan as Governor of DKI Jakarta (AB), Ridwan Kamil as Governor of West Java (RK), Fadjroel Rachman as spokesman for President (FR), Achmad Yurianto as spokesman for government regarding Covid-19 (AR), Fadli Zon as member of House of Representative from Gerindra (FZ), Hariyadi Sukamdani as Chairman of Indonesian Businessman Association (HS), and Tulus Abadi as chairman of Harian YLKI (TA). The assertive speech acts that appear in the talk show can be seen in Table 1.:

\section{Table Of The Use Of Assertive Speech Act In Mata Najwa Program "Gara - Gara} Corona"

\begin{tabular}{|c|c|c|}
\hline No. & $\begin{array}{l}\text { Assertive Speech } \\
\text { Act }\end{array}$ & Number \\
\hline 1. & Telling & 11 \\
\hline 2. & Stating & 6 \\
\hline 3. & Suggesting & 3 \\
\hline 4. & Making Proud & 3 \\
\hline 5. & Reporting & - \\
\hline
\end{tabular}

Based on the table, the use of assertive speech act in Mata Najwa can be identified 23 speech pairs. The number of assertive speech act is divided into 11 pairs of telling, 6 pairs of stating, 3 pairs of suggesting and 3 pairs of making pride. Based on the table, kind of assertive speech act that is used most is telling, while assertive speech act of reporting is not found at all in the segment of speech.

\section{Assertive Speech Act of Telling}

Assertive speech act of telling is speech informing something to interlocutor. In segment of speech in Mata Najwa, episode "Gara-Gara Corona" (because of Corona), there are 11 pairs of speech act of telling. This is the most found in this segment. Some of them are:

NS: I want ask specifically that's breaking news, there is one foreigner about 54 years old number 25 that died. Did he die because of the other hereditary disease? 
AY: actually since he came to Indonesia we have noted many hereditary diseases, such as diabetes, hypertension, chronic lung obstruction and hypeceroid. Those had already suffered since more than 5 years and before coming to Indonesia, he had stopped by Qatar.

In speech no.1, interviewer asked about the hereditary disease suffered by case number 25 , assertive speech act of telling was used by interviewees in informing about many hereditary diseases from foreigner that died, interviewees also told to interviewer that hereditary had been suffered more than 5 years by foreigner.

Assertive speech act told this also like speech number 5, in this context interviewer asked to interviewees about was it important for many people checked covid-19. Assertive speech act of telling was used by interviewees to inform to interviewer and audience that not as many people as possible should be checked but as many people as should do tracing. The thing can be seen as follows

NS: was it important for as many people as possible to be checked?

AY: not as many people as possible checked but as many people as possible did tracing, so without reason we did not do checkup .

\section{Assertive Speech Act of Stating}

Assertive speech act of stating is a speech or expression that functions to explain or describe something to interlocutor. In segment of speech, Mata Najwa episode "Gara - Gara Corona" (because of corona), there are six pairs of speech act of stating, some of them are:

NS: I want to clarify Sir Yuri, because the patient was in Bali. After there was statement from regional government that to not inform the result of checkup to patient and public health office, so they had known that the patient in Bali had Corona when he had died, was it true?

AY: We have found positive cases and then tell to doctor directly as patient in change, because this part is as nursing service. Indeed, demand from region tells to not be published and is not our authority, and doctor in charge of patient must know because it is patient's and doctor's right to know.

On the speech number 3 above, interviewer asks about whether is right that government does not inform checkup result of patient's case in Bali to patient and local health office, so interviewer ask to clarify of that case. The answer given by Achmad Yurianto as interviewees is statement, he says that after finding positive case of covid-19, government will tell doctor directly as patient in charge, because of his opinion, that thing is part of management of nursing service. Besides data of speech above, assertive speech act states that there are speech number 14, can be seen from quote:

Prepared, can't we start beginning quicker?

FR; actually government's preparation has been begun when there were case of Mer and Sar. Then government made instruction of president number 4 year 2009 about ability improvement in preventing, detecting and responding of epidemic of global disease, nuclear sovereignty, geology and chemistry.

On the speech above, interviewer asks whether the government can begin quicker without waiting protocol in handling covid-19, the answer in form of statement is conveyed by Fadjroel Rahman, he said that the government had have preparation and had been begun previously when there were case of mers and sars, he also explains about the instruction made by government regarding epidemic of global desease.

\section{Assertive Speech Act of Suggesting}

Assertive speech act of suggesting is speech or expression functioning to give suggestion or opinion to someone to do whether is suggested. In speech segment of Mata Najwa episode "Gara - Gara Corona", there are 3 pairs of suggesting speech, they are:

AB: Indonesia is facing this situation right now but we have example, in Wuhan, in China in December and January. Then these some weeks happens in Europe, Iran, Korea we witnessed two extraordinary jumps. We are able of these two choices, first choice, taking route like Iran, Amerika, South Korea, and Italia. What did they do?, being relax, doing 
limited test. The number increase gradually. In Italia on 20 February there are 4 cases, in 18 days become 9.172, it is extraordinary, the government act to do closing, restriction all. Second choice, there are Singapore, Vietnam, and Selandia Baru. What did they do? They did that was done by countries but it is in t beginning phase. Jakarta, we submitted all and we said that we would do that was done in the beginning phase, so there was no improvement of case number.

In speech number 8 above, assertive speech acts of suggesting that are used by Anies Baswedan as the interviewees. He suggested two choices or two models that could be emulated to handle Covid-19 in Indonesia. As he has explained in the speech, the first choice that can be made is to take routes such as Europe, Iran, and Korea. Then the second route he suggested was to take the route like Singapore, Vietnam, and also New Zealand.

In addition to the example above, assertive speech act of suggesting can also be found in utterance no. 22. In these utterances, assertive speech acts of suggesting that are also used by Anies Baswedan, he said that we must change the stigma ie not to worry and not feel bad / ostracized if it turns out positive was infected Covid-19 because according to him the fact that if positive, patients are not considered bad instead will be in a container. This can be seen from the following quote.

$\boldsymbol{A B}:$ There is one thing that is very important, Nana. This is not a disgrace. This is not a virus due to wrong behavior, which is distorted, is not. This is familiar to being infected. If we shake hands, chips can be infected. This means we have to change the stigma, so there are no worries. That when positive it becomes bad. Not! If it's positive, we will contain it.

\section{Assertive Speech Act of Making Proud}

Assertive speech acts of making proud are utterances or expressions that serve to express pride. In the speech segment of the Mata Najwa program episode "Gara-Gara Corona", three pairs of proud speech acts were found, some of which are:

FZ : I appreciate the spokesperson for this corona, Mr. Achmad Yurianto is better than the Minister of Health in addressing this to the public.

In utterance number 17 above, the assertive speech act of making proud was used by Fadli Zon as a guest speaker from the House of Representatives Commission 1 member, he expressed his pride towards the government spokesperson related to Covid-19, namely Achmad Yurianto, because he had given the information or provided information related to Corona Virus to public with good language. Actual assertive speech acts can also be seen in utterance no 23, following the quote:

In addition to the central government and regional government, the most important thing is actually the active nature of the community. Why is case I and case II so interesting and we consider both men to be human heroes, because they report. We hope that every one of these 257 million will be active, not just leaving it to the central and regional governments.

In the above statement, the assertive speech acts boast of being used by the president's spokesperson, Fadjroel Rahman. He expressed his pride to the people of case number I and case number II so he considered the two men to be human heroes

\section{CONCLUSIONS}

Based on the results of the study it can be concluded that the assertive speech acts that appear in the speech title totaled 23 pairs of utterances. The most assertive speech acts that appear are the speech subtitles which tell about 11 pairs of utterances. This speech act is used by informants because it serves to inform the opposite person of something. That is what then underlies the type of assertive speech acts that many appear in the event. In addition to these types, the assertive speech act used by the resource person is the speech act states, suggests, and boasts. The speech sub-actions used have their respective functions. As for the type of assertive speech acts the reported speech sub-actions were not found at all in the event. 


\section{REFERENCES}

Austin, J. L. (1962). How to Do Things With Words. New York: Oxford University Press.

Chaer, A. (1994). Linguistik umum. Jakarta: Rineka Cipta.

Elinni, M, Juita, N \& Hamidin. (2014). Tindak tutur ilokusi ustaz yusuf mansur dalam acara wisata hati di stasiun televisi antv. Padang: Universitas Negeri Padang.

Izar J, Afria R \& Kamiyatein. (2020). Bentuk dan Fungsi Tindak Tutur Ekspresif dalam Filmdokumenter The Mahuzeskarya Watchdoc Image. Jurnal Lingue: Bahasa, Budaya, dan Sastra.2(1). 1-11

Kusumaningrum, F. (2018). Tindak tutur dalam pidato pasrah tinampi pernikahan masyarakat Jawa: Sebuah kajian sosiopragmatik. Surabaya: Universitas Airlangga.

Leech, G. (1983). The Principle of Pragmatics. Terjemahan ke dalam Bahasa Indonesia dilakukan oleh M.D.D. Oka. 1993. Prinsip-Prinsip Pragmatik. Jakarta: UI Press.

Pradita, S.R, Wuryaningrum, R. \& Widjajanti, A.. (2015). Tindak tutur asertif dalam acara dr.oz Indonesia di trans tv. Jember: Universitas Jember.

Ramanda, A. D, Ermanto \& Novia Juita. (2017). Tindak tutur ilokusi pada pidato kenegaraan presiden jokowi tanggal 14 agustus 2015. Padang: Universitas Negeri Padang.

Sudaryat, Y. (2009). Makna dalam Wacana.Bandung: CV. Yrama Widya.

Surakhmad, W. (1982). Pengantar Penelitian Ilmiah. Jakarta: ??

Tarigan, H. G. (1990). Pengajaran Pragmatik. Bandung: Angkasa.

Yule, G. (2006). Pragmatik. Yogyakarta: Pustaka Pelajar. 